\title{
CIVIL RESISTANCE VS ENVIRONMENTAL IMPUNITY IN THE BAY OF PUERTO MARQUÉS, ACAPULCO, MEXICO
}

\author{
HERNANDO AVILES, TERESA DE J. RIVAS, MA. ELVIA CHAVARRÍA, \\ JORGE E. MUÑOZ S. \& ÁNGEL DE J. JAIMES \\ Faculty of Tourism, Universidad Autónoma de Guerrero, México
}

\begin{abstract}
The Bay of Puerto Marqués, in the city of Acapulco, is marked by conflicts related to land restraints and expropriation decrees, as a result of its geography and wealth of tourism resources. The alteration of the Bay of Puerto Marqués landscape and its environmental degradation are due to the impunity that prevails in the governmental authority. This paper aims to analyze the alteration of the environment, the complicity of the authorities, the environmental impunity and brokenness of companies of the Marquesanos in regard to the civil resistance that has occurred over two decades. Residents of the local community have confronted government intimidation with force, exposing their own lives to save their cultural heritage. The methodology of the research is qualitative because the paper explains the social and cultural attitudes of the local context. Since 2010, the government authorized a development at the Majahua marine, for which there was a 1.7 hectare marine fill, violating existing regulations; meanwhile the Environmental Impact Statement clearly states the damage to the bay and the effect on tourism service providers. In underdeveloped countries such as Mexico, environmental sustainability is a key area of study, but there are few observed positive actions because of impunity.

Keywords: expropriation, environmental impunity, civil resistance.
\end{abstract}

\section{INTRODUCTION}

Mexico is the third country with the greatest diversity on the planet, which is a privilege but represents a great commitment to conserve a large number of species. Therefore, it is imperative that the institutions of the Mexican state can counteract the deterioration that human activities generate in the environment. The geographical position of Mexico has placed it between two major climatic regions, where warm and cold marine currents converge, which allows a great variety of climates and ecosystems. This same has allowed an important development of the tourist activity, coming to represent one of the important economic activities.

Acapulco in the coastal zone of the Pacific Ocean for its natural beauty has been a prominent pole of the national tourist activity. However, the lack of planning, the overexploitation of its resources and, in many cases, the deficient performance of the institutions of the government levels, have caused a significant environmental deterioration.

The Bay of Puerto Marqués and its beaches are part of the conservation area of the port of Acapulco, Mexico. Its geography and the spectacle of nature is a contemplative ecstasy of the backwaters of pleasure for tourists. Diamond Zone complements Acapulco with a beach length of $4.2 \mathrm{~km}$; it is made up of a nearly 16 contiguous beaches at Majahua and Pichilingue.

Located in a mountainous area of reliefs and plains, this space has become the most expensive in the city due to its scenic beauty. Acapulco houses, condominiums, and luxury apartments are plentiful, as they continue to occupy privileged spaces of natural settings along the scenic avenue of nine kilometers that connect Acapulco with the Bay of Puerto Marqués. This development trend fueled by the tourism industry expel local populations, expropriate ejidal territories, and create a dichotomy of wealth and poverty. This paradigm is set in juxtaposition sustainable, local development that should reflect according to Serrano 
[1] "social equity and economic benefit, to improve the quality of life, from the proper use of resources to maintain the ecological balance".

The deliberate actions of the government of the State of Guerrero have generated opposition from the population to be stripped of property that for years has been their way of life. In order to further enable the tourist development of Acapulco, the state has resorted to the legal concept of expropriations to convert a third of the tourist zone of Acapulco called Zona Diamante, affecting the towns of Puerto Marqués. This causes socioeconomic struggles for generations of natives against the governmental authorities.

The Governor of the State of Guerrero, Cervantes [2] initiated the legal mechanism of dispossessing Ejidal lands in the population center of Copacabana belonging to the town of Puerto Marqués. The peasants were deceived because they were informed that their property titles would be respected. They soon began to be intimidated into abandoning the prized coastal zone that rich entrepreneurs coveted.

The residents of Puerto Marqués Bay have always been involved in disputes, which over time have become more violent as they have faced the authority in civil resistance. Their lands have been perennial scenarios of grievances due to the fact that they are a coveted tourist resource, whose economic impacts only benefit the government and tourist developers.

Leaving the negative impact to the population, impacting hostility and social tension are not compatible in communities that usually showed warmth to the visitor. The resistance is caused by the marginalization and exclusion that are subject by entrepreneurs and tourism developers indifferent to residents' daily lives. Paradigm questioning, is tourism really a tool of sustainable development in underdeveloped countries like Mexico?

\section{EXPROPRIATIONS AND INEQUALITY STRENGTHEN TOURISM DEVELOPMENT}

The objective of the research is to determine the effects on the environment and natural resources of the Bay of Puerto Marqués in Acapulco and the civil resistance that its inhabitants have presented to the government of the State of Guerrero. This is motivated by the tourism boom that has generated favorable conditions of public policies to expropriate the land to peasants exposed to the power of the hegemonic state, through successive expropriation decrees the first on 12 June 1992 "it is declared of public utility and the expropriation is decreed in favor of the decentralized organism of the government of the State of Guerrero, Promotora Turística de Guerrero, the land without construction, located in the

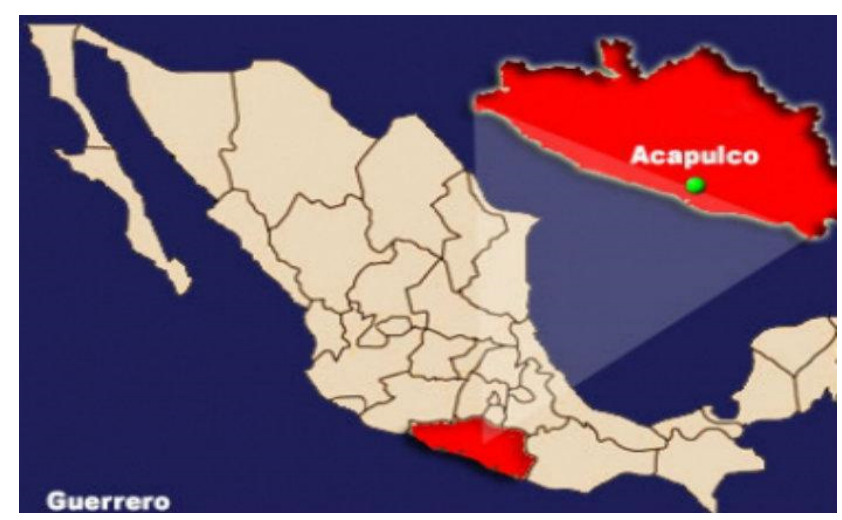

Figure 1: Map of Mexico. 


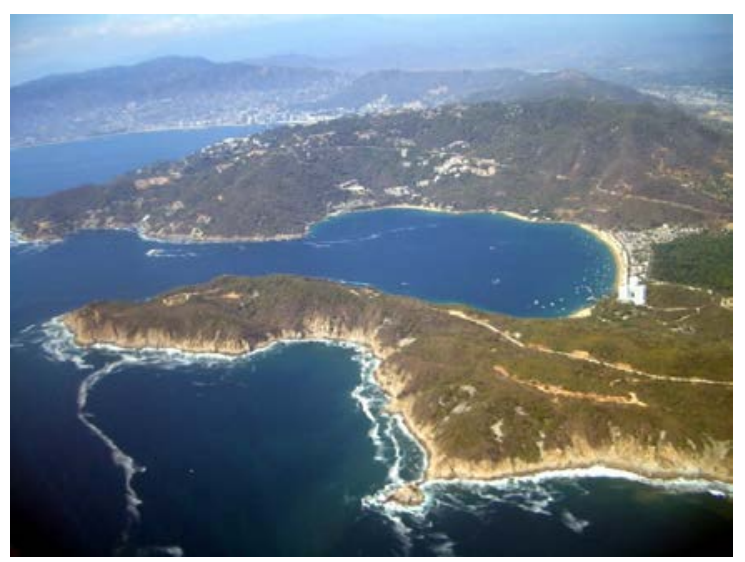

Figure 2: Map of the Bay of Puerto Marqués.

tourist integration zone known as the Diamond Zone, in order to comply with the objectives foreseen in the Law of Tourist Promotion with an area of 240,661.12 $\mathrm{m}^{2}$ " for 8 September $1992,41,240 \mathrm{~m}^{2}$ were expropriated with the same purpose.

On 25 September 2001 the final blow was struck with the expropriation of $321,561.66 \mathrm{~m}^{2}$, dislodging the residents of the region from the entire coastal area and moorland. Derived from the unlimited expropriation of land to peasants and placing them in places far from the coastal zone, changing their way of life to reconvert them as small micro-entrepreneurs or living from the usufruct of the lands to be gardeners, watchmen, drivers, porters, that is to say, employees of the touristic developers.

Moreover, the population nucleus that still survives from restaurants and water sports rental faces a last harassment by allowing the federal government the construction of a marina with an outcome of severe damage to the ecosystem of the Bay of Puerto Marqués foreseen in the Environmental Impact Manifesto (EIM). The marquesanos also continue to defy the authority because of the evident environmental deterioration, organizing themselves in civil resistance.

\section{METHODOLOGY}

The research is of a qualitative nature "because it explains social aspects, cultural, opinions and attitudes of a documentary nature since it tries to explain reality in its context" (Joubish et al. [3]). When analyzing authors, the concomitance of ideas reflect the objective of the work. The collection of information is made by observation, exploration and description of anomalies and events that occur in the study area.

For its development, interviews were held with the population, merchants and public officials, which were carried out and documented through taking photographs, observation, notes and field trips. Giving importance to the opinions and experiences that allowed to discover the main problems that show the environmental deterioration that the community faces when participating as a hostess directly and be affected with the construction of the Majahua marine that generates an impunity to the coastal ecosystem of the Bay of Puerto Marqués, as well as the repercussions that it has brought to the environment by diverting the marine currents and disappearing the beach area because of micro-entrepreneurs.

The research required frequent visits to the study area and the use of approach techniques for the collection of information, observation, and review of documents, e-books, web pages 
and talks with relevant local characters. The in-depth interviews were conducted with three important sectors of the population, residents, merchants and government officials. This furthered the understanding of the damages inflicted to the environment and the environmental impunity that prevails with the approval of the authority and the resistance of the population.

In the first stage, field trips were made to know the geo-ecological damage to the beaches that reconfigured the landscape with evident damages to the natural beauty of flora and fauna. Authors that address a straight and truthful positioning of a public policy such as the federal law of environmental responsibility that is issued to stop abuses of businessmen and concealing authorities that are sold, and transgresses the regulations to favor big capital to the detriment of the environment, were examined. In a second stage, authors were identified that deal with the permissiveness of the authority and its governance that adduce rhetoric so as not to apply the norms to suit their interests, transgressing its own raison reason to be and in another aspect perceived omission. The scope of the study is also descriptive since it describes the effects that have caused grievances and loss of heritage to the population upon entering their place of residence, impunity, bringing with it a series of changes that society as a whole has had to face.

\section{ENVIRONMENTAL IMPUNITY}

Environmental degradation is one of the main problems facing humanity, "The wrong development model has put in the spotlight of all countries the need to respect the rules of natural balance, to ensure the integrity and renewal of natural systems," (Protocol of San Salvador [4]).

In the environmental issue there has been historical impunity; "there is a marked refusal to recognize the interests and benefits of recognizing that the urgency of the environmental issues" (Folch [5]) because it is a threat that looms over the planet, where it is endangering the continuity of the human species. The tendency has been to concentrate on seeing the impacts and mitigating them, as a result of declarations, forums, agreements, protocols and summits. A cluster of legislation, commitments without monitoring or evaluation of its benefits.

"The scientific community's concern is that now it is recognized that the planet's resources are limited" (Foley [6]) there is a lack of meaningful action to protect one's inherent right to enjoy a healthy and ecologically balanced environment. In Mexico, the norm establishes criteria for all aspects of sustainability. That is in marked opposition to the will that leads to environmental impunity. It is discouraging that Mexican legislation is not applied or if it is applied, it is at the discretion of officials in turn, when exemptions are established, privileging economic development, and undermining ecosystems.

According to Soto [7] "assures that impunity is the lack of punishment, in law, impunity is de facto and de jure." The right includes the extinction of responsibility under the amnesty, pardon or prescription. The de facto includes crimes that go unnoticed to justice, either because the authors escape the action of this or lack of sufficient evidence to be convicted. The Royal Spanish Academy defines that impunity is lack of punishment.

The ecological crime must arouse the widespread moral contempt and the total rejection of public opinion, because impunity exists at the moment that is not punished those who commit unlawful acts against the environment [5]. In the case of environmental impunity, those responsible for the main environmental crimes, environmental damage and the consequences to the affected populations such as the community of Puerto Marqués are government decisions. These are closely linked to the hegemonic structures that hold the 
capital and the government's need to gather resources that underpin the weak economy of the government, without the scrupulosity of transparency in the rendering of accounts.

Environmental impunity has distorted the tourist development of Acapulco, inexorably changing its natural tourist space to give way to huge blocks of concrete buildings symbols of the prosperity of the big cities that resulted from the forced expropriations carried out to found the Diamond Zone in Acapulco that (Zapata and Agatón [8]) "has forged more than 40,000 second-residence rooms" radically distorting the essence of the expropriation, which was based "on the need for the tourist destination of Acapulco to have a territorial reserve for future hotel growth, as well as, of ecological reserve for its sustainable development" (Cisneros [9]).

When Leff [10] warned that the response of the State to the processes of deterioration had been late, especially given its accelerated pace and its cumulative nature. Given that the government reasons for expropriation were those of generating protected areas, ecological zones, the commercialization of the land was established at incalculable economic margins, which in a few cases has also served for speculation, payment of political favors and complicity of government.

Businesses that do not reflect in the regional development that for many years was fed into government plans that tourism (Ruíz [11]) would be the trigger to eliminate the backwardness and poverty of the population and that this would increase the welfare levels of the population. Despite this, today, the two values of Acapulco persist: that of wealth in the main tourist strip and that of poverty behind the hills. It is clear that the exclusion of the fragmented society has been attempted to be incorporated into tourism's economic development.

The lack of compliance with the Territorial Ecological Management Program, as an instrument of public policy, which is mandatory in the entire national territory and has the purpose of linking the actions and programs of the Federal Public Administration that must observe the environmental variable in terms of the Law of Planning [12]. There is regulation, but weakness in its application, since the coastal spaces are the most appreciated. They are seen as mutually exclusive commercialization opportunities, due to corruption and impunity.

García [13] reports impunity is considered as the lack of punishment; as a problem that has disrupted the legal, social and economic security of Mexican society; has limited the confidence of citizens in criminal justice institutions; has violated the legal order and social welfare to which Mexicans aspire to live.

Impunity was a prologue to the proliferation of subdivisions that devastate the landscape of the once beautiful coastal areas and wetlands "investors and developers, these last entrepreneurs who build sell and leave, apply a model that has been defined as 'real estate model' being the axis of the same investment. There is recovery in a short time because they leave the externalities, expressed in infrastructure and provision of basic services, for the municipality or hotel operators, who must face these costly operations that should have been solved from the beginning of the works declare" (Arnaiz and Dachary [14]). In this sense, Quintana [15] recalls that "sustainability is not an option, it is the path. In nature there are no rewards or punishments, there are consequences."

The tourists eager to touch and live the experience of swimming, sailing or fishing, contemplating landscapes, without precise instructions and clear rules of use and enjoyment of the tourist attraction have spoiled it, contaminated its natural resources, approaching a utopia the possibility of sustainable development . By polluting the beaches with wastewater, as well as with debris and sand, luxurious developments built a few meters from where the waves break in Puerto Marqués. "Everything has been privatized, buoys were placed to prevent residents from approaching oyster fields, fishing, or diving ensures" (Arciniega [16]). 
The construction of the Majahua marine, which since October 2010 begins its construction, has been added to the already completed collapse, taking an area of 2 hectares of beach to the bay of Puerto Marqués, with the stone and gravel filling that is made to build the piles that will contain the force of the waves, causing the deviation of the marine currents, foreseen in the Environmental Impact Manifest (EIM) and that the Secretariat of the Environment and Natural Resources [12] avoids in total collusion with the Mexican Development Group. The affected residents consider the work completely rude, offensive to the community, because the large tourist developments no longer provide tourists, they bring environmental problems that consider them irreversible.

It is a contradiction to the smoothness with which the regulations are applied, when there is evidence of damage, a public policy is avoided that by its nature is required to any work that ruins or alters the environment "the environmental impact assessment is an instrument of the environmental policy, whose objective is to prevent, mitigate and restore damage to the environment as well as the regulation of works or activities to avoid or reduce their negative effects on the environment and human health. Through this instrument, development options are proposed that are compatible with the preservation of the environment and the management of natural resources" [12].

The EIM limits the seriousness that will be caused to the ecosystem with the construction in process, given the amount of materials discharged to the beach, a considerable amount of fish will perish, which, in the face of unusual contamination, will lose their sense of location, fishing will be significantly reduced, and in general, all molluscs species throughout the area will become extinct.

When the beach disappears, the continuous waves will undermine the foundations of the restaurants until they are knocked down, which will be a good thing for the developers since finally the owners of the affected restaurants will disappear, since their food establishments will contrast with the beauty that pretends to be the emblematic Majahua marine that will lodge luxurious boats.

Regarding the severity of the environmental degradation, according to Barnard [17] it is considered that it cannot be measured on a scale of one to 10 , however, it is estimated that due to severe damage, the sediment has caused organisms from both flora and fauna cannot be oxygenated and in some cases, like fish, they have to disperse to other parts of the sea in the face of the contingency of the environment.

\subsection{Civil resistance, more active role of local actors}

Since the World Tourism Organization (WTO) [18], through its section of fast news emanating from all member countries alerted daily about actions that shake consciences by deliberate perjuries that are undertaken against the environment for the sake of tourism development by meriting spectacles of contemplative nature, exhorting the civil society to get involved and be active actors of the community to contain everything that harms the environment.

Contributions to extend the knowledge of the most relevant is made worldwide. The analysis of this news in order to identify what could be significant trends that are affecting the configuration of the legislative agenda of tourism, as well as in general in the definition of public policies of a country. Because tourism is the object of many reflections, but of very few actions, or at least of very few effective actions.

It is evident, points out [18] that tourism is a phenomenon that is fundamental at the local level, so it does not seem strange to point out that there is a greater degree of intervention in the definition of tourism policies, of all and each of the local actors, as could be seen in the 
protests of local fishermen for the construction of Disney in Hong Kong, facing civil resistance in a country that seemed implausible.

What is civil resistance in Mexico? Civil resistance is a kind of non-violent action. It is a wide range of activities and constant, against a certain power, power, politics or the regime, hence the term resistance. The adjective civil in this context denotes that the one that corresponds to a citizen or society, that is, it is time to change a system and create something new to go to another paradigm [19].

Civil resistance must be a collective action that avoids any recourse to the violence that is generated and is exercised by the civilian population that requires an organizational and planning process for its effectiveness and, finally, must be based on an element of moral force that legitimize [20].

Aridjis [21] recommended that through civil resistance and civil protest of all social sectors, students, peasants, popular classes and middle class can be done something against impunity, a government that turns a deaf ear to justice, evident, from one side of the country to another and that has already exploded to intolerable levels.

The restaurateurs live in distress since the beach disappears due to the deviation of the ocean currents the onslaught of the waves is undermining the structures, leaving bare the foundations of premises, which will eventually succumb, coupled with the fact that customers do not attend because they lack beach, however, that the (EIM) demanded as a rule by [12] warns of the devastation that will cause the ecosystem by the change of marine currents, to cover the water sand the beach disappeared. Violating all normativity, the work continues.

Restauranteurs, boatmen and fishermen defy the authority with marches, and have marched to Mexico City to request an audience with the President of the Republic without success because the work takes an advance of $80 \%$ that still resist the malice of the authority that recognizes the irreversible damage to the area for the benefit of developers and the loss of micro-entrepreneurs. From November 2010 to August 2016, the marquesanos have lived moments of high tension, anxiety for the police encirclements, fights with the developers and until the constant eviction of workers of the navy, which has been an obstacle for its conclusion. Before the threat that the inhabitants face, they organize themselves, they manifest themselves, blocking avenues, closing government offices, since thousands of fish wake up dead on the shores of the beach.

Desolate pose as their sources of life languish in agony, without any possibility on the horizon of the rescue of its translucent waters; in spite of this, the change in land use continues to change indiscriminately in favor of urban development, giving rise to impunity, with the massive construction of housing subdivisions demanded by the Acapulco tourist growth, which according to (Sancho [22]). The developmental vision of tourism, based on the principles of the capitalist market, assumes that this activity produces important economic benefits from the flight of landscape resources and cultural goods.

The Marquesans complain that since 1994 they have denounced the ecocide that the big investors have made, but regret that "the environmental authorities, the deputies and the same state government have overlapped the deterioration of both the environment and our oyster fields, of ax callus, locust". Arciniega [16] emphasizes, "that they have sent trades to the governor of the state to request audiences, which have been forgotten: nevertheless, we will continue to fight even at the cost of giving our lives". Of the activism displayed by those affected, expressing their displeasure with curses such as "with the marine they gave us in the whole mother," (Palma [23]) claiming the stretch of beach that the sea covered in less than six months.

Providers of tourist services and restaurateurs perform insistent marches on water to indicate that there is no longer the beach that supported families for generations, with banners 
and allusive pints demand the government of the state solution and insist on the ecocide of species such as fish, oysters, and turtles "do not want handouts we are starving, we want to return us to the beach to work," (Castrejón [24]).

The damages to the bay of Puerto Marqués are the shared responsibility of the touristic developers and fishermen of the area due to the overexploitation, so both parties will have to assume their responsibility in the environmental damages, they are accusations that mutually are rebuffed, while the authorities remain far away letting the population get tired, slowing civil resistance, because otherwise the construction permit would be withdrawn from the Majahua marine, the marquesanos argue.

A study conducted since 2012, by the National Fisheries Institute INAPESCA [25], explains that in one of the areas of Puerto Marqués, southern part, "there is a decompaction of soils, the opening of gaps and deforestation carried out by real estate developers of the Diamond Zone, generated hauling of stones, earth, mud and organic matter through the Majahua stream and other natural causes which caused the reduction of the rock oyster population and the disappearance of the red clam banks that is to say that alerts exist, however, as in many cases, economic interests prevail over ethics, an archetype that permeates mature tourist destinations and those that are integrally planned, associated with environmental impunity" [25].

The change in land use has caused deforestation, erosion, water pollution, and the loss of flora and fauna. In addition, social problems, according to Martínez [26] such as the presence of socioeconomic marginalization, malnutrition, unemployment and/or deterioration in income levels, illiteracy, poor health and high drop-out rates in the community are added, leaving few options for improving the quality of local life.

In the dissent of the settlers of Puerto Marqués against those responsible for allowing the project authorities responsible for the damages to the landscape, as Vega [27] mentions evades in the environmental impact statement that has the [12] is very clear, says that the promoter must compensate the damage that the work takes place. In addition, it is also obliged to carry out a technical-scientific study to determine the type of damage, because it was not the first modification in the federal zone and compliance with the conditions is seen by the Federal Attorney's Office for Environmental Protection so that as long as it persists conspiracy of the authority in the application of the law the marquesanos defend themselves against the threat of losing their patrimony.

The eruption of civil resistance in Puerto Marqués is reinforced as a result of expropriations that have diminished their ability to coexist in a government project that does not contemplate their inclusion, without truce they are attacked, confused, hold meetings with responsible authorities that only extend, the crisis while the marine Majahua is consumed.

Faced with the work stoppage for periods, due to the recurring sit-ins of the providers of tourist services, the state government has chosen to divide those involved, the providers of aquatic services, such as restaurateurs, boatmen, jet skis, sailors have been summoned to offer them the payment of an indemnity of 1 million pesos for each micro-entrepreneur.

\section{RESULTS}

To change the marine currents, to disable $500 \mathrm{~m}^{2}$ of beach, dramatically changes any scenario, the maximum of divide and conquer is used openly by the government of the State. In the study of the follow-up to the case of the environmental impunity that has been given to the construction of the Majahua marine, a public policy of the need to generate income to the state government can be noticed, even in the detriment of the coastal zone and natural and underwater resources. 
Money to be distributed percentage to those affected, with the promise that they will provide employment as pawns during the period of completion of the marine and then have priority in the permanent recruitment in the operation of the marine at least 50 workers, in masonry tasks, painting, gardening and manual sweeping action that has left them unsatisfied. Disappearing their cooperatives to become pawns.

Restaurateurs and providers of tourism services continue the fight with available resources, researchers of the Faculty of Tourism and the Faculty Marine Ecology of the Autonomous University of the state, will contribute with a comprehensive study of environmental impact, with the acquiescence of the federal and state authority in clear collusion of the authorities involved, because the sighting to repair the damage is irreversible given the amount of tourist developer investment.

The admonitions of environmental groups, the activity deployed for five years by local actors, will have been useless, leaving only the feeling that was made unthinkable, leaving a sample of civil resistance vs environmental impunity, however, the prevailing corruption in the levels of government have a price before the rapacity of big capital.

\section{CONCLUSION}

More than two decades ago, the sustainability of tourism activity continues to be handled only in a figurative sense, as evidently occurs in the bay of Puerto Marqués, the reality is that there is no will and no control to reach such a desired goal, environmental impunity prevailing.

The work has modified the landscape of the entire bay and has already affected in a very important way the beach of Puerto Marqués, which have been eroded causing the sea to advance significantly, affecting until collapsing nearby buildings and reducing the beach. This has scared away tourism, causing the locals to live in danger.

Likewise, the construction of the Majahua marine has affected the environment and caused coastal erosion directly, since it obstructs the current that distributed sand to this portion of the bay, the construction by its location and size has modified the dynamic stability condition that it has deteriorated the loss of the beach.

Faced with the adverse conditions facing a large number of destinations, before this seemingly unstoppable chaos. Will the investors and their capital sit idly by? It is understood that no. The examples show that in the face of unfavorableness, ethics and scruples will be ignored by greed. The civil resistance of local actors will be vital.

The tourist destinations on the coasts and beaches are the most demanded sites, consequently the impact on them has been - in some places - devastating as the construction of the Majahua marine in the bay of Puerto Marqués. Water quality care is emerging, especially as long as the models of intensive development continue to prevail.

\section{REFERENCES}

[1] Serrano, B.R., Tourism as a sustainable local development factor. Keynote address given in the Universidad Autónoma de Guerrero, 23 May 2015.

[2] Cervantes, D.A., Gobernador constitucional del Estado de Guerrero, 1981-1987.

[3] Joubish, M.F., Khurram, A.M., Ahmed, A., Fatima, T.S. \& Haider, K., Paradigms and characteristics of good qualitative research. World Applied Sciences Journal, 12(11), pp. 2028-2087, 2011.

[4] Protocol of San Salvador, Protocolo adicional a la Convención Americana sobre Derechos Humanos en Materia de Derechos Económicos, Sociales y Culturales, 17 Nov. 1998. 
[5] Folch, R., Ambiente, Emoción y Ética. Actitudes ante la cultura de la sostenibilidad. Editorial Ariel, Barcelona, España, 1998.

[6] Foley, J., Límites de un planeta sano. Instituto de Medio Ambiente de la Universidad de Minnesota, en la revista Investigación y Ciencia. España, pp. 23-28, 2010.

[7] Soto, A.C., Selección de términos jurídicos, políticos, económicos y sociológicos. México Ed. Limusa, 1996.

[8] Zapata, P. \& Agatón, D., Investigación aplicada para determinar impactos de segunda residencia en la Zona Diamante. Financiado por la Secretaría de Turismo de Turismo del gobierno del Estado de Guerrero, 2012.

[9] Cisneros, J.R., Expropriation decree. Gobernador constitucional del Estado de Guerrero (1999-2005), 2001.

[10] Leff, E., Introducción a una visión global de los problemas ambientales en México. En Medioambiente y desarrollo en México CIIH. UNAM. México, 1990.

[11] Ruíz, J.F., Plan de gobierno, gobernador del Estado de Guerrero, 1987-1992.

[12] EMARNAT, Secretaria del Medio Ambiente y Recursos Naturales, Procuraduría Federal de Protección al Ambiente. Estudios de impacto ambiental, 2008.

[13] García, S.R., Impunidad y corrupción factores que han minado la confianza y credibilidad en las instituciones públicas. Revista digital ticsm.org, 7(1), pp. 2-3, 2011.

[14] Arnaiz, B.S. \& Dachary, A., From the tourist boom to the environmental crisis. Presented at 10th Encuentro Internacional Humboldt. Rosario, Santa Fe, Argentina, 2008.

[15] Quintana P.M., Presidente experiencias Xcaret. Discurso al recibir la presea de la Confederación Nacional Empresarial Turística (CNET), 7 Jun. 2012.

[16] Arciniega, E.A., Personal communication, 4 Jun. 2015, President of the Cooperative Society of Fishermen and Divers of Puerto Marqués, Acapulco.

[17] Barnard, Á.J., Personal communication. 6 Mar. 2015, Biologist, director of the company Carlos Ochoa Sistemas de Inmersión. A.C. (COSIAC).

[18] World Tourism Organization, WTO News 1998, Press releases. www.wto.org/english/news_e/pres98_e/pres98_e.htm. Accessed on: 11 Jan. 2017.

[19] Resistencia civil México, http://resistenciacivilenmexico.blogspot.mx/. Accessed on: 2 Dec. 2017.

[20] Resistencia civil en México, http://español.answers.yahoo.com/question/index? Accessed on: 2 Dec. 2017.

[21] Aridjis, H., Conference to conclude participation in the presentation of the book ¿Que es la poesía? de Lawrence Ferlinghetti, en el patio del Instituto de Artes Gráficas. Oaxaca, México, 2011.

[22] Sancho, A., Introducción al turismo. Organización Mundial de Turismo, (OMT) Madrid, España, 1998.

[23] Palma, H.A., Personal communication, 8 Apr. 2016. Micro-entrepreneur in gastronomy.

[24] Castrejón, P.A., Personal communication, 5 Jun. 2015. Micro-entrepreneur from the bay of Puerto Marqués.

[25] Instituto Nacional de Pesca (INAPESCA-2012).

[26] Martínez, J.A., Manejo local de la microcuenca Lagunillas, Jalisco, México: Análisis del manejo ocio Ambiental de la microcuenca Lagunillas en Jalisco, México, España: Editorial Académica Española, 2012.

[27] Vega, V.D., Personal communication, 8 Apr. 2012. Delegado Federal de la Secretaría de Medio Ambiente y Recursos Naturales (SEMARNAT). 